\title{
Marijana Terić
}

Fakultet za crnogorski jezik i književnost, Cetinje

marijana.teric@yahoo.com

(iD https://orcid.org/0000-0002-6801-9299

\section{Periferni likovi u romanu $U$ registraturi Ante Kovačića}

Sažetak: U radu autorica sagledava djelo jednog od najznačajnijih stvaralaca hrvatske književnosti Ante Kovačića, čiji roman U registraturi mnogi književni kritičari i teoretičari smatraju najboljim ostvarenjem hrvatskoga realizma. Riječ je o autoru koji nije bio shvaćen u vrijeme kada se njegovo djelo pojavilo, zbog čega se na publikovanje romana čekalo dvadeset i tri godine. Nelinerana kompozicija teksta, elementi fantastičke književnosti i inovativan literarni postupak u kreiranju fabularno-sižejnog toka događaja, zbunjivali su književne kritičare epohe realizma, kao i čitalačku publiku, što ukazuje na činjenicu da je Ante Kovačić dugo tretiran kao periferni autor. Budući da se u romanesknom djelu opisuje bijeda i bespomoćnost seljaka i njihov revolt protiv feudalnog gospodstva u Hrvatskoj, predmet naše analize biće usmjeren na karakterizaciju likova iz različitih društvenih slojeva, s posebnim fokusom na „periferne likove“ Kovačićeve proze. Terminom „periferni likovi“ pokušaćemo približiti one likove potčinjenih seljaka u odnosu na feudalno-kapitalistički društveni sloj i tako naglasiti njihovu ulogu u djelu u odnosu na ostale junake i njihove sudbine.

Nasuprot likovima seljaka: Ivice Kičmanovića (koga društveno uređenje pretvara u lakeja i podlaca), Jožice Zgubidana (oličenje siromašnog Zagorca), Anice (patrijarhalne djevojke anđeoskog lica), Mihe, Perice, susjeda Kanonika, Medonjića, Kovačić nam donosi grube, drastične slike moralnih posrtanja u gradu, a u kojima dominiraju figure izobličene do karikature. Suprotstavljanjem seoske sredine gradskom životu, autor piše „,epopeju sela i grada“ u kojoj ,periferni likovi“ postaju tragični. Ti su likovi nosioci elemenata „fantastičkog realizma“, pri čemu je njihova funkcija da prikažu sve izopačenosti jednoga društva i najave pojavu inovativnih postupaka pripovijedanja bliskih autorima moderne književnosti.

Na kraju dolazimo do zaključka da je Ante Kovačić svojim djelom napravio iskorak u odnosu na generaciju realista pri čemu periferna pozicija njegova stvaralaštva nestaje pojavom modernih literarnih ostvarenja, čime autor i njegovo djelo, konačno, dobivaju zasluženo mjesto u hrvatskoj književnosti.

Ključne riječi: Ante Kovačić, fantastički elementi, inovativni postupci, demonski likovi, društvena izopačenost 
Ante Kovačić pripada generaciji hrvatskih pisaca osamdesetih i devedesetih godina 19. vijeka koje karakteriše nacionalna i politička potčinjenost zemlje Austro-Ugarskoj Monarhiji. To je vrijeme naglog prodora kapitalizma i sve većeg siromaštva ljudi, naročito seljaka koji pružaju otpor organizovanjem raznih pobuna i borbi. Vodeća ličnost književnog života bio je urednik lista Vijenac August Šenoa, najznačajniji predstavnik stilske formacije romantizma, ali i autor koji je otvorio rani period realizma u hrvatskoj književnosti. Određeni Šenoinim djelom, javljaju se mladi hrvatski realisti (Ante Kovačić, Eugen Kumičić, August Harambašić) koji će se svojim idejnim programom odigrati važnu ulogu u hrvatskoj književnosti. Najznačajniji među njima bio je Ante Kovačić koga smatraju izdankom Šenoina djela i baštinikom Šenoina nasljeđa u književnosti hrvatskog realizma. ${ }^{1}$ Budući da su glavni predstavnici hrvatskog realizma uglavnom bili ljudi iz grada, „karakteristično je da se u najvećem dijelu hrvatskih romana iz vremena realizma seljak gotovo i ne pojavljuje, ili, ako se pojavljuje, čini to samo usput, a katkad i u vrlo nesimpatičnu osvjetljenju“.2 Kao dječak iz sirotinjske seoske porodice koji se školovao u gradu, Ante Kovačić unosi lik seljaka u književnost, slikajući njegove probleme, njegov položaj u svijetu i unutrašnje preokupacije, stvarajući tako individualne junake svoje proze kao predstavnike određene društvene sredine. Miroslav Šicel navodi da je Kovačić jedini realist koji je uspio osvijetliti panoramu društvenih odnosa:

Nije se samo obračunavao sa strancima i političkom tradicijom Hrvatske - ta je problematika bila samo jedan, i to gotovo usputni aspekt njegova stvaralaštva. Mnogo je važnije to što je naročitu pažnju pri izboru tema posvetio problematici klasnih i socijalnih odnosa u hrvatskom društvu druge polovine 19. stoljeća. ${ }^{3}$

Iako je tematika sela bila karakteristika literature evropskih realista, „nije se u toj literaturi o selu osjećala težnja pisaca da zahvate seoski život u njegovoj cjelini i u njegovim izvorima“4 ${ }^{\star 4}$. Čini se da je Ante Kovačić jedan od rijetkih autora koji je svoje djelo posvetio upravo seljaku kao

\footnotetext{
${ }^{1}$ Mate Lončar, „Dvojnost stvarnosti i mašte,“ u U registraturi, aut. Ante Kovačića (Beograd: Rad, 1981), VIII.

2 Antun Barac, „Selo u djelima hrvatskih realista,“ u O književnosti (Zagreb: Školska knjiga, 1986), 142.

${ }^{3}$ Miroslav Šicel, „Književnost predrealizma i realizma,“ u Hrvatska književnost (Zagreb: Školska knjiga, 1982), 101.

${ }^{4}$ Barac, „Selo u djelima hrvatskih realista,“ 143.
} 
čovjeku koji ima svoj unutrašnji život, čovjeku koji osjeća, pati, strada, čime je napravio zaokret u postupku građenja fabule i oblikovanju svoje vizije realističkog manira slikanja stvarnosti. Najbolji izraz književnog stvaranja Kovačić je ostvario u svom posljednjem romanesknom ostvarenju $U$ registraturi, koji se ujedno smatra i najboljim romanom hrvatskog realizma. Djelo se prvi put javlja u časopisu Vijenac 1888. godine, gdje izlazi u nastavcima, dok je integralan tekst publikovan 1911. godine. Roman je izazvao brojne reakcije čitalaca, tako da je kritikovan zbog svoje neobičnosti, proglašavan „nevaljalnim i pogubnim štivom kojim se truju hrvatska srca“. ${ }^{5}$ Optuživali su autora zbog izrazitog pesimizma, crnila i mračnih, demonskih likova. Najžešće kritike Kovačićeva djela uputio je zagrebački nadbiskup Ante Bauer koji je svoj napad iskazao u formi pisma i uputio uredništvu Vijenca kako bi izvršio pritisak i obustavio objavljivanje romana u čemu je i uspio. ${ }^{6}$ Nijedan izdavač u Hrvatskoj nije se usudio da izda roman zbog čega se štampanje djela u posebnu knjigu čekalo dvadeset i tri godine. Kako Milanović ističe, zahvaljujući kritičarima hrvatske moderne oživljeno je interesovanje za Kovačićev roman koji napokon dobiva zaslužene ocjene.? Milan Marjanović upozorava da „ni jedan hrvatski pisac nema takva načina pripovijedanja, takve mašte i temperamenta, a ujedno takva oštra opažanja i karakteristična opisivanja." ${ }^{\text {" }} \mathrm{U}$ svom tekstu „Buđenje Ivice Kičmanovića“ Ivo Frangeš ukazuje na zablude tadašnje kritike, njihove predrasude i nemogućnost da shvate „neurednu“ kompoziciju Kovačićeva djela, inovativnost forme, kao i elemente fantastične književnosti, ${ }^{9}$ dok je Matoš napisao da se ovaj autor za tadašnje prilike rodio pedeset godina ranije te da se Kovačićev roman ,pojavio u vrijeme kad ga ni kritika, a pogotovo prosječni čitatelji, nisu mogli razumjeti. Odviše se razlikovao od svega što se tada držalo reprezentativnim modelom romana".10

Pomenuta dešavanja koja su pratila stvaralački rad Kovačićeva romana impliciraju autora koji se, odstupanjem od poetičkih konvencija, izdvojio od svoje generacije hrvatskih realista te, zbog upotrebe različi-

\footnotetext{
${ }^{5}$ Branko Milanović, „O Kovačićevom romanu $U$ registraturi,“ u $U$ registraturi, aut. Ante Kovačića (Sarajevo: Veselin Masleša, 1978), 5.

${ }^{6}$ Marijan Jurković, Ante Kovačić (Beograd: Prosveta, 1950), 25.

${ }^{7}$ Milanović, „O Kovačićevom romanu $U$ registraturi, “ 5.

${ }^{8}$ Milan Marjanović, „Dr. Ante Kovačić,“ u Hrvatska književna kritika (Zagreb: Matica hrvatska, 1950), 91.

9 Vidi: Ivo Frangeš, „Buđenje Ivice Kičmanovića,“ u Stilističke studije (Zagreb: Naprijed, 1959).

${ }^{10}$ Strahimir Primorac, Zvjezdani pepeo (Zagreb: Mozaik knjiga, 2003), 7.
} 
tih stilova i tehnika, dugo tretiran kao „periferni autor“. Pojam periferni u ovom kontekstu upotrijebljen je da označi jednu pojavu koju zbog njezine autentičnosti nije bilo moguće shvatiti u vrijeme kada se pojavila. U Kovačićevu djelu prepoznaje se sinteza triju poetika: realističke, romantičarske i naturalističke, u okviru kojih možemo pratiti određene likove. S obzirom na to da je predmet našeg rada ukazati na značaj perifernih likova u romanu $U$ registraturi pokušaćemo da opišemo jedinstvene likove seljaka kao periferne junake hrvatskog seljaštva u čije se probleme nijedan autor prije Kovačića nije zagledao. Budući da djelo opisuje hrvatsko društvo druge polovine 19. vijeka, autor je obuhvatio dug raspon kako bi prikazao veliki broj likova; od izrazito realističkog lika Ivice Kičmanovića, fantastičkog babe Hude ili romantičarskog lika Laure. Zanimljivo je da se na okvirima romana, kao likovi, javljaju oživljeni spisi sudske arhive među kojima se vodi žučna rasprava, tako da roman priča životopis registratora Ivice Kičmanovića obuhvatajući vrijeme od njegova djetinjstva do trenutka kad, zatečen u Laurinoj sobi, mora napustiti Mecenin dom. Interferencijom realnih i fantastičnih elemenata, nelinearnim pripovijedanjem i razgranatim fabularno-sižejnim tokom događaja, Kovačić je ostvario modernost umjetničkoga postupka te potvrdio da je riječ o djelu koje zahtijeva moderna književna tumačenja. Ovako „čudnovati“ litearani postupak bio je neobjašnjiv mnogim kritičarima toga doba. Dimitrije Vučenov pronalazi da Kovačićeva polemika među fasciklama u sudskoj arhivi slična postupku engleskog pisca Đonatana Svifta u njegovu djelu Bitka knjiga. Radnja romana smještena je u Sent-Džemsku biblioteku, u kojoj bibliotekar razmješta knjige u bibliotečkom fondu kako bi novim piscima obezbijedio najbolja mjesta na policama. Međutim, stare knjige dižu pobunu i zahtijevaju da budu vraćene na mjesta koja im priliče. Kako Vučenov objašnjava, nastaju dvoboji između raznih autora (Aristotela i Bekona, Homera i Fontenela i drugih), a onda se Bitka knjiga prekida mistifikacijom, tipičnom za Svifta, da je završetak rukopisa izgubljen. ${ }^{11}$ Ova knjiga nije prevedena kod nas, pojašnjava Vučenov, tako da je bila nepoznata čitaocima južnoslovenskih prostora čime se ukazuje na to da Ante Kovačić nije mogao znati za ovaj pripovjedni postupak kada je pisao svoje djelo. Iako okviri priča dviju knjiga $U$ registraturi i Bitka knjiga korespondiraju jedan drugom, Kovačićev postupak predstavlja novinu i značajan kvalitet njegova djela u hrvatskoj prozi, koji Frangeš objašnjava riječima: „Ima

${ }^{11}$ Dimitrije Vučenov, „Predgovor,“ u U registraturi, aut. Ante Kovačića (Beograd: Prosveta, 1978), 10. 
pisaca, koji razvijaju teme, ima ih, koji razvijaju tehniku“", ${ }^{12}$ ukazujući tako na narušavanje ustaljenih književnih obrazaca i inovativnost forme kojom je autor obogatio svoju književnost.

Budući da je Kovačić svoj život proveo u razočaranju, patnji, borbi za boljim životom, odraz te borbe, ,tog rvanja s prilikama i neprilikama, i neprijateljima, ličnima i narodnima, stvarnima i fiktivnima, raspoloženje je, što ga je Krleža u svom eseju o Kranjčeviću nazvao laurizmom“.13 Tragičan udes koji ga je zadesio, Kovačić ispoljava u najsnažnije modelovan ženski lik Laure, po kojoj je nastao pojam laurizam. Pojavu ovog termina objašnjava nam Branimir Donat u svom čuvenom tekstu „Na Hoffmannov način“, čiji dio eksplicitno navodimo:

Sve ono što u stranim književnostima označujemo terminima satanizam, dijabolizam, a izraz je najdublje ambivalentnosti doživljaja, dakle sve ono što je naoko abnormalno, no stvaralački uvjerljivo, mogli bismo u pomanjkanju boljeg termina, kada je riječ o hrvatskoj literaturi, okrstiti imenom LAURIZAM, koji je prvi upotrebio Miroslav Krleža.

Možda je malo neobično ime, no samo dotle dok se ne sjetimo Laure, junakinje Kovačićevog romana $U$ registraturi i njene fenetičke pojave, neobjašnjive i poetične. Njen somnabulizam, pervertiranosti, čudesnost scena u kojima živi svojom izrazitom romanesknom psihologijom, sve su to osobine koje nas zanimaju. Tako ovim divnim romanom, čudesnoj i čudnoj amfibijskoj kombinaciji analiza najtanjih stanja jedne morbidne i senzibilne mašte, uprljane svježom tiskarskom bojom tek otisnutih špalta najbanalnijeg potrošnog, feljton-romana, mi u hrvatskoj novijoj književnosti prvi put susrećemo san kao stvarni, a ne kao do tada - samo alegorični medij nekog romanesknog zbivanja. Ante Kovačić bio je jedan od prvih naših stvaralaca koji je riječ san shvatio ne samo ako dekorativni epitet (uostalom i Goethe ju je upotrebljavao u metaforičnom i dekorativnom značenju), a u tom je značenju koristi čak i veći dio naše suvremene poezije, iako vjeruje da njome izražava suštinu svog stava predmetima pjesme - već kao jedinu mogućnost dubokog življenja. ${ }^{14}$

\footnotetext{
12 Frangeš, „Buđenje Ivice Kičmanovića,“ 203.

13 Frangeš, „Buđenje Ivice Kičmanovića,“ 208.

14 Branimir Donat, „Na Hoffmannov način,“ Delo, god. VIII, br. 6 (1962): 718-719.
} 
Laura nije samo „primjer romantičarskog lika fatalne žene, već lika spuštenog do razine trivijalnog modela junaka iz tzv. hajdučke naše novelistike pedesetih godina“. ${ }^{15}$ Ona je „Fatum, ona je degenerirana životna sila, koja savladava i staro i mlado, i nosi razor i nesreću, strahotu i zvjerstvo u svom nagnuću za životom, za ljubavi, za užitkom“. ${ }^{16}$ Ovo je lik koji ostavlja snažan utisak svojom vrelom krvi, svirepošću i demonskom figurom koja dominira romanom. Zbog ovakvog postupka u modelovanju njezina lika koji postaje ekstreman, možemo govoriti o Lauri kao perifernom liku, bliskom hajdučkim romanima ili romanima fantastičke književnosti. Periferan lik u ovakvom bi kontekstu označavao junaka koji ne pripada svojoj epohi (stilskoj formaciji realizma), već se personifikovanjem njezinih strasti i požuda odlazi u sferu nadrealnog ili fantastičnog. Dakle, Laura pripada posebnom literarnom univerzumu koji se $\mathrm{u}$ vrijeme pojave romana ne nalazi u centru realističkog pripovjedačkog tkanja, već pripada perifernom stilu hrvatske književnosti.

Ivica Kičmanović, čiju nam sudbinu retrospektivnom metodom pripovijedanja otkriva životopis registratora s početka romana, predstavlja posebno modelovanog junaka Kovačićeva romana. Iako su kritičari u njemu vidjeli životni put mnoge seljačke djece koja odlaze u grad za boljim životom, lik Ivice Kičmanovića zahtijeva mnogo kompleksniju psihološku analizu. Na početku djela pratimo njegovo odrastanje na selu, isticanje plemenitih osobina dječaka i izdvajanje od druge seoske djece talentom i marljivim radom. Dolaskom u kuću svog „dobrotvora“ Mecene, Ivičin život doživljava potpunu transformaciju. Od seoskog dječaka koji nevinim pogledom na život upoznaje mračnu stranu gradske sredine u kojoj se ne pronalazi, Ivica odrasta u zrelog momka koji postaje žrtva fatalnog ženskog lika Laure. Tako se na fabularnoj osnovi romana prati ispovijest triju likova: Ivice Kičmanovića, Laure i Mecene, kao izrazitih predstavnika perifernih likova u djelu. Iako Ivica upoznaje Lauru u gradu, u kući „dobrotvora“ Mecene, Laurino porijeklo i otkrivanje njezina biološkog oca Mecene koga ubija, nalazi svoje korijene u mračnoj sredini, svirepom i gnusnom činu iz kojeg se rađa demonska Laurina figura. Opisom ovih likova doprinosi se mračnoj atmosferi romana, a smještanje radnje u dvorac ili samostan srednjovjekovnog razdoblja podsjeća na obilježja gotske priče, odnosno gotskoga romana, pri čemu tajanstveni događaji, srednjovjekovni ambijent i opis kuće,

\footnotetext{
${ }_{15}$ Miroslav Šicel, Pisci i kritičari (Studije i eseji iz hrvatske književnosti) (Zagreb: Naklada Ljevak, 2003), 134.

${ }^{16}$ Marjanović, „Dr. Ante Kovačić,“ 98.
} 
mračni zapleti i mračna atmosfera djela upućuju na neke elemente fantastičkog realizma.

Pojedini kritičari, poput Milana Marjanovića, smatraju da se među najbolje stranice hrvatske proze realizma ubraja djetinjstvo i prva ljubavna noć Ivice Kičmanovića i njegovo buđenje u Laurinoj sobi. „U prozi hrvatske književnosti 19. vijeka nikad i nigdje dotad nije ocrtana tako erotski naelektrisana atmosfera, tako smiono, $i, u$ isto vrijeme, u kontekstu junakove duševnosti i njegova prelaza iz djetinjstva u mladićstvo, kao i u oblikovanom i smisaonom kontekstu romana, tako uspjelo." ${ }^{\text {"17 }}$ Ova epizoda predstavlja ključnu ulogu u životu glavnoga junaka koji postaje žrtvom svog seljačkog porijekla i fatalne žene za koju Šicel piše da je onaj usud „koji isključivo vodi ljudske sudbine, nemoćne da se odupru sili kojom ih vodi u propast; ona je motivacija često realno neobjašnjivih postupaka junaka s kojima dolazi u direktni kontakt, oslobodilac zla koje prirođeno tinja pritajeno u svakoj ljudskoj individualnosti, manifestirajući se, prije ili kasnije u jačem ili slabijem obliku u društvenim i međuljudskim odnosima“ ${ }^{18}$ Prvi susret s Laurom Ivica opisuje ovim riječima:

Ja ispadoh iz odaja mecene i sretnem na stubama divnu Lauru... Ona mi se nasmiješi rajskim, požudnim osmijehom, a u crnim očima usplamsa joj strast i hladnoća, neopisivo milje i ljut prezir, anđeoska dobrota i zmijska zloba..., sve to $\mathrm{u}$ jedan tren...

Ah, Laura..., ta Laura! ... ${ }^{19}$

Laurin lik okarakterisan je nizom kontrastnih osobina što implicira podvojenu ljudsku prirodu, anđeosko i đavolje u nama, dobro i zlo, život i smrt. Opijenost njezinom ljepotom i erotskim nabojem s početka romana prerasta u mržnju i želju za uništenjem koju nalazimo u pismu koje Ivica upućuje Lauri:

... Na: Vi ste, zabludjela i iskvarena griješnica, unišli u mecenin dom kao trgovkinja sa svojom vlastitom ljepotom i dražestima a mene ste ondje našli, koga već iskvariše, istrgavši me iz nevine i slatke seljačke koljevke $\mathrm{i}$ od čistih majčinih grudi... Vi ste bili iskusni i lukavi - kako i ne u Vašem staležu i zanimanju? Ja sam Vam se svidio i Vi se zaželjeste moje mladosti, koja se

\footnotetext{
${ }^{17}$ Milanović, „O Kovačićevom romanu $U$ registraturi,“ 12.

${ }_{18}$ Miroslav Šicel, Kovačić (Zagreb: Globus, 1984), 136.

19 Ante Kovačić, U registraturi (Beograd: Rad, 1981), 64.
} 
već bijaše pretočila iz djetinjstva u mladića, a Vi je zatekoste u naponu i najljepšoj raspupalosti momačke svježosti i duševne zanešenosti... ${ }^{20}$

Svjestan svoje naivnosti pred svirepošću „harambaše“ Laure, Ivica Kičmanović pokušava da se oslobodi njezine neprijateljske sile, želi da pobjegne iz grada kao simbola poroka i grijeha i odlazi na selo kako bi pronašao svoju sreću u ljubavi koju djevojka Ančica osjeća prema njemu. Lik Ančice predstavlja suštu suprotnost Lauri. Kao patrijarhalni tip djevojke božanskoga lica, Ančica je jedan od rijetkih likova u romanu koja je simbol topline, ljubavi, požrtvovanja, nevinosti, anđeoskog pogleda, čija dobrota biva kažnjena svirepim zločinom na kraju djela. U priči „Krvava svadba“ Ančica umire u krvoločnom činu u kojem joj Laura otkida grudi. Tim zločinom Laura potvrđuje demonsku figuru u romanu, a njezini zvjerski zločini (ubistvo oca Mecene, Mihe i Ferkonje) svoju kulminaciju dobivaju u toj sceni ubistva. Osakaćeno tijelo djevojke, čije su oduzete grudi simbol ženstvenosti, senzitivnosti, čulnog, erotskog, predstavlja osakaćen lik Laure koja ovim đavoljim ubistvom prestaje biti čovjekom. Njezin lik dobiva odsustvo ljudskih osobina i prerasta u mračno stvorenje, personifikaciju demonske sile, koje i Ivicu Kičmanovića vodi u smrt. Iako se Ivica Kičmanović smatra centralnim likom romana, Laura je pokretački mehanizam radnje i jezgro djela. Ona je povezana sa svim likovima, počev od Ivice, kumordinara Žorža, Mecene, babe Hude, Ferkonje, Mihe, Kanonika, Ančice... „Ona je udes sebi, ona je udes čitavoj knjizi“ ${ }^{21}$ Roman završava junakovim psihičkim rastrojstvom. On se odaje alkoholu i u deliričnom stanju u registraturi izaziva požar u kojem će i sam izgorjeti.

Nećete, ne, okrutnici! I onako je već na 'krvavoj svadbi' uništena svaka svrha moga života... Tek me još vuče i goni po svijetu ovo jadno tijelo! Prah, pepeo i blato! ...

Što da još krzmam? Što da još izgledam? Ah, to će biti divno, božanstveno - ha - ha- ha! Ipak je Lura majstorica! Oh! Laura! ... Laura!... I upali luč, baci je u tekućinu, i što bi okom trepnuo, usplamti sve i probukti strašan oganj, te razorna vatra zahvati svu registraturu...22

\footnotetext{
${ }^{20}$ Kovačić, U registraturi, 394.

${ }^{21}$ Milorad Živančević i Ivo Frangeš, Povijest hrvatske književnosti. Knjiga 4 (Zagreb: Liber i Mladost, 1975), 404.

${ }^{22}$ Kovačić, U registraturi, 458.
} 
U posljednjim trenucima života Ivica se sjeća Laure, a dozivanjem njezina imena „usvaja njen životni stav: uništenje kao životni poriv i nužnost!“233 Milanović ukazuje na značajan simbol vatre kao uništenja koje je očekivan ishod junakova sloma u romanu: „Vatra tu ima simboličan smisao nesvodljiv na samo jedno značenje: ona je paklena, ludačka osveta, i pobuna protiv prividnog životnog reda i eto, u slučaju kao što je ovaj, spas iz haosa!“24 Iako je Laurin lik toliko snažno prikazan da dominira čitavim djelom, smrti dvaju junaka, Ančice i Ivice, kao perifernih likova Kovačićeva djela, izdižu se nad Laurinim „hajdukovanjem“ jer oboje stradaju zbog ljubavi i kao žrtve Laurine nesrećne sudbine.

Za razliku od likova koji čine jezgro romana, realistički modelovani jesu likovi Jožice Zgubidana, zlog susjeda Kanonika i njegovih sinova Pera i Mihe. To su likovi koji se po svojim karakternim osobinama razlikuju pa se mogu paralelno pratiti njihove osobine. Jožica Zgubidan seljački je muzikant, ,vesela ljudina“, „čovjek suh, nasađen na dugačkim, tankim nogama“25, a susjed Kanonik ,čovjek malen, nabit, krupan, kratka vrata i debele jake glave“ ${ }^{26}$ Kontrastno su prikazani i Kanonikovi sinovi: „Miho bijaše prava slika i prilika svoga oca. Malen, jak, otresit i crnomanajst dječarac; teško je učio, a još manje znao“. ${ }^{27}$ Pero je prikazan kao tih, povučen dječak koga su svi voljeli zbog mirne prirode. Bio je „bjelokos kao janje, a slabušan i mekan poput kanarinca“ i uvijek je „sanjario i zanosio se u neki nama nepoznati svijet“. ${ }^{28} \mathrm{U}$ modelovanju ovog lika prepoznaju se elementi romantičarske stilske formacije, kao i posebnog tipa oniričke fantastike, a to su vidoviti snovi, koji su dati u funkciji modelatvornih principa, oni san pretvaraju u javu tako što se dešavanja u snu prevode na polje stvarnosti. Da pojasnimo.

Romantičarska vizija života, sanjarenje i odlazak u iracionalnu sferu sastavni su dio Peričine sudbine koja ga je vukla u neki drugi svijet kojemu se on „mišicom usne“ smiješio. Jednom prilikom kada ga je učitelj pitao zašto nije učio, Perica odgovara da je sanjao da su „došli anđeli po njega da ga odvedu u neku, daleku, veliku i beskrajnu livadu punu zelenila i cvijeća. Slatko me celivaju i grle, te mi šapću da

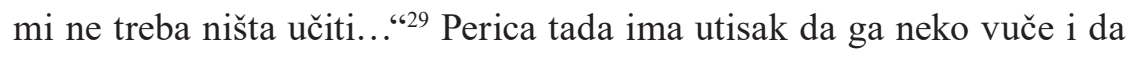

\footnotetext{
${ }^{23}$ Milanović, „O Kovačićevom romanu U registraturi,“ 8.

24 Milanović, „O Kovačićevom romanu $U$ registraturi,“ 8.

25 Kovačić, U registraturi, 13.

26 Kovačić, U registraturi, 13.

27 Kovačić, U registraturi, 26.

28 Kovačić, U registraturi, 27.

29 Kovačić, U registraturi, 26.
} 
će poletjeti. Ovaj san ima proročku funkciju jer Pericu zaista odvode anđeli: „...Tek je izlepetao tankim ručicama poput ranjene ptičice kad umirući krilima uzleprše..., izvrnuo široko oči, iz kojih potekoše vrele suzice... i usnuo zavazda, te se preselio k svojima anđelima, o kojima je toliko puta slatko i čudnovato snivao..."30

Mnogi likovi u romanu mogu se posmatrati kao oponenti. Osim Jožice Zgubidana i Kanonika, Mihe i Pere, Mihe i Ivice, snažnu karakterološku opoziciju čine Laura i Anica. Prva je izrazito demonska, hajdučka figura, a drugu vidimo kao „tanku vilu iz gorice“ i „nevini seoski anđelak". ${ }^{31}$ Misteriozno porijeklo likova, pustolovna zbivanja i fantastički elementi dati su kroz dvije retrospektivne radnje u cilju slikanja životnih puteva Mecene i Laure. Mecena je predstavnik gradske sredine, predsjednik društva „Poniznosti i ustrpljivosti“ u čiji je lik Kovačić inkorporirao osobine gluposti, licemjerstva i propadanja moralnih vrijednosti. Iako ga u plemićkom društvu nazivaju „dobročiniteljem“, Mecena je oličenje pokvarenosti, zlobe i bolesnog koje nalazimo u epizodi o njegovu porijeklu. Laura je dijete Mecenina grijeha, posljedica silovanja „gizdave vile“ Dorice koja će nakon tog životinjskog čina poludjeti i postati prosjakinjom. Tragičnost ovog lika sadržan je u riječima „Srce mi vrati! Dušu mi vrati! Poštenje mi vrati! ${ }^{\text {(32 }}$ Izrazito fantastičan lik je baba Huda, „visoka, tanka, otrcana i suhonjava starica, sagnuta tijela“"33, blijeda i mršava lica, šiljasta nosa, staklenih, sitnih i zelenkastih očiju. Čudnovatost staričina u pustoši u kojoj pronalazi Lauru i pomaže joj da se vrati u gradsku sredinu, asocira na misteriozne likove iz bajki koji se pojave niotkuda, a potom nestanu u neki tajanstveni prostor.

U kreiranju lika ružnog i ćoravog dječaka Ferkonje, Kovačić se služio realističkim postupkom kako bi prikazao svu negativnost, zaostalost i zvjersko u čovjeku. To zvjersko nastaje noću kad se odigrava silovanje Laure, a potom i ubistvo Mihe. Ovo je izrazito negativan lik koga Laura u djelu naziva ćoravom rugobom, a koji obilježava njezino djetinjstvo i asocira na scenu Mecenina silovanja Dorice, grijeha koji rađa Lauru. Time je Laurin lik predodređen za zlo koje nadvaladava cjelokupna zbivanja u tekstu. U prvom dijelu romana lik Ferkonje opisan je kroz Laurino djetinjstvo, dok se na kraju romana eksplicitno pojavljuje, ali ne više kao dječak, već kao mladić:

\footnotetext{
${ }^{30}$ Kovačić, U registraturi, 41.

31 Aleksandar Flaker, Stilske formacije (Zagreb: Naklada Liber, 1976), 187.

32 Kovačić, U registraturi, 149.

33 Kovačić, U registraturi, 195.
} 
Taj svat bijaše ćorav na jedno oko, ali ga obasuše silni brkovi i brada. Lice i tijelo redio je i glatkao, da je bio tijelom pravi atlet, a obrazima poput kakove izgubljene djevojke, koja je već davno proigrala prve pupoljke divne mladosti svoje, a sad samo lovi u tanke mreže svojih požuda i svoje ljepote šarene, jednodnevne leptire, što najradije nadlijeću na rascvalo i prezrelo cvijeće. (...) Laura u njem prepozna starog ćoravca Ferkonju. Ali kolika je razlika od onda i sada! Taj novi svat tek škilji na zdravo oko, podsmijeva se na Lauru, pa se šali, ponavlja i govori da mu nitko neće haka doći... ${ }^{34}$

Laura i Ferkonja osvetnički su motivisani likovi, izrazito mračni, pa se kao takvi svrstavaju u tipove razbojnika koji čine razne zločine. $\mathrm{Na}$ taj način te likove tretiramo kao periferne u smislu provincijalizma, zaostalosti, rušilačke funkcije u romanu.

Posebnom tipu likova pripada kumordinar Žorž, rođak Ivice Kičmanovića koji odlazi sa sela u grad da bi služio bogatom Meceni. Kumordinar Žorž zaboravlja na svoje seljačko porijeklo izigravajući gospodina, a ta mu uloga nikako ne pristaje. Pohlepa, zavist, primitivizam, samo su neke od karakternih osobina tog seljaka.

I oca je naš rođak Jurić gostio jelima i pićem kakova on nikada na nijednoj svadbi vidio ni mirisao. Više bijaše Juriću na umu njegova vlastita oholija i taština nego li dobro djelo. 'E, da vidiš, moj kukavni rođače, što je gospodski život i da znaš pripovijedati u našem prnjavoru kako li žive u slasti i lasti gospodin kumordinar Žorž, prvi pod lustrišimušom! Gle, uživaj pa pamti!'... ${ }^{35}$

Tragikomičnost toga lika sastoji se u nesaglasnosti između onoga tko je on i šta bi volio da bude. Kumordinar Žorž, Mecenin sluga, naziva sebe gospodinom kako bi se izdigao iz sredine iz koje je potekao. „Vrijedni kumordinar Žorž“ i „rođakinja Laura“ bijahu dva bića čudnoga Mecenina doma. ${ }^{36}$ Jasno je da je svaki junak u romanu nosilac Kovačićevih ličnih konflikata što ukazuje na opoziciju različitih poetičkih strujanja. Zato je većina epizoda ostvarena „,izrazito naturalističkim potezima, crnim, fatalističkim slikama, isticanjem

\footnotetext{
34 Kovačić, U registraturi, 434.

35 Kovačić, U registraturi, 37.

${ }^{36}$ Kovačić, U registraturi, 212.
} 
primarnih čovjekovih uglavnom negativnih, neobuzdanih i stihijskih instinkata". ${ }^{37}$

Možemo konstatovati da je Kovačić stvorio jedinstvene likove seljaka čime je pomjerio realistički manir pripovijedanja. Šicel nam objašnjava: „Ako je nešto novo Kovačić unio u hrvatsku književnost svog vremena, onda je to sigurno posebni ugao iz kojeg on posmatra i analizira svoje junake i društveno-političke događaje, kao i način na koji prezentira svoje teme“".38 Ako pomenemo samo ulogu Laure oko koje se plete cjelokupna radnja romana, možemo reći da je ona specifičan tip koji doprinosi dinamičnosti djela i čini njeno jezgro. Osim toga, ona je „tipičan lik intriganta s ciljem da ovezuje događaje, daje im snagu akcije i dinamike, zapetljava i otpetljava radnju..."39 Zbog takvih ekspresivnih ili, po riječima kritike, pretjeranih osobina njezina lika, u književnosti je nastao već pomenuti termin laurizam. Nije nam poznato da je u hrvatskoj književnosti formiran sličan pojam nastao na projektovanju nekog lika kao što je to slučaj s djelom $U$ registraturi u kojem je Laura zamišljena kao sporedna, a ne glavna junakinja. Romantičarsko literarno stvaranje prvenstveno njezina lika, a onda i ostalih likova koji nijesu tipični predstavnici stilske formacije realizma, objašnjava perifernu poziciju autorova djela. Recepcija romana nastalog u epohi realizma iznenadila je kritičku i čitalačku publiku zbog čega je bilo potrebno da prođe izvjesno vrijeme kako bi Ante Kovačić bio valorizovan na valjan način.

Pregledom kritičkih sudova, postaje jasno da je Kovačić tipični primjer talentiranog, izvanserijskog hrvatskog pisca koji je doslovno izgorio u učmaloj, maloj, malograđanskoj našoj sredini, nedorasloj da shvati dalekosežnost njegovih literarnih inovacija, otvaranje novih tematskih prostora, utvrđivanje poetike modernog realističkog romana... ${ }^{40}$

Iz tog razloga smatramo da je autor djelom $U$ registraturi stvorio autentične likove seljaka, kao i onih iz gradske sredine, koje smo u radu posmatrali ne samo u kontekstu opozicije periferija-centar, već smo pojam periferno vezali za onaj tip likova koji se svojim psihološkim portretom izdvajaju, pa kao takvi ne pripadaju ili samo odstupaju od

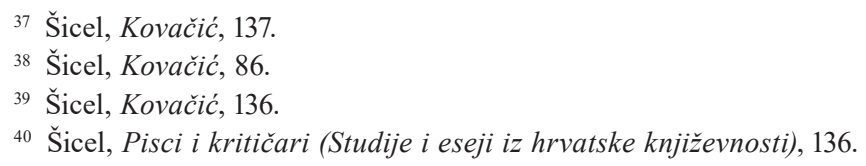


hrvatske književnosti razvijenoga realizma. Njihova funkcija u romanu jeste da prikažu hod vremena, položaj hrvatskoga društva, društvene i političke krize čovjeka, tako da Kovačićevi likovi izviru iz „te bujice vremena i zbivanja, i nestaju opet $u$ njoj - njihove su sudbine samo dio tog vremena i tog zbivanja“".11 Izrazito romantičarsko i fantastičko pripovijedanje upotpunjeno slikama stvarnosti, društveno-analitičkom funkcijom djela i socijalno-psihološkom motivacijom, čine osnovna poetička načela Kovačićeva literarnog postupka, karakterističnog za autore moderne književnosti. Takvom koncepcijom romana Kovačić je ostavio najtrajniji dokument kritičkog realizma u Hrvatskoj.

\section{Literatura}

Barac, Antun. „Selo u djelima hrvatskih realista.“ U O književnosti. Zagreb: Školska knjiga, 1986.

Barac, Antun. „Čitajući Kovačića.“ U O književnosti. Zagreb: Školska knjiga, 1986.

Donat, Branimir. „Na Hoffmannov način.“ Delo, god. VIII, br. 6 (1962): 705-721.

Flaker, Aleksandar. Stilske formacije. Zagreb: Naklada Liber, 1976.

Frangeš, Ivo. „Buđenje Ivice Kičmanovića.“ U Stilističke studije. Zagreb: Naprijed, 1959.

Jurković, Marijan. Ante Kovačić. Beograd: Prosveta, 1950.

Kovačić, Ante. U registraturi. Beograd: Rad, 1981.

Lončar, Mate. „Dvojnost stvarnosti i mašte.“ U U registraturi, autora Ante Kovačića, V-XII. Beograd: Rad, 1981.

Marjanović, Milan. „Dr. Ante Kovačić.“ U Hrvatska književna kritika. Zagreb: Matica hrvatska, 1950.

Milanović, Branko. „O Kovačićevom romanu U registraturi.“ U U registraturi, autora Ante Kovačića, 5-12. Sarajevo: Veselin Masleša, 1978.

Primorac, Strahimir. Zvjezdani pepeo. Zagreb: Mozaik knjiga, 2003.

Vučenov, Dimitrije. „Predgovor.“ U U registraturi, autora Ante Kovačića, 7-20. Beograd: Prosveta, 1978.

Šicel, Miroslav. „Književnost predrealizma i realizma.“ U Hrvatska književnost. Zagreb: Školska knjiga, 1982.

Šicel, Miroslav. Kovačić. Zagreb: Globus, 1984.

Šicel, Miroslav. Pisci i kritičari (Studije i eseji iz hrvatske književnosti). Zagreb: Naklada Ljevak, 2003.

Živančević, Milorad, i Frangeš, Ivo. Povijest hrvatske književnosti. Knjiga 4. Zagreb: Liber i Mladost, 1975.

${ }^{41}$ Marijan Jurković, Ante Kovačić (Beograd: Prosveta, 1950), 17. 


\section{Peripheral Characters in Ante Kovačić's Novel U Registraturi (In the Registry Office)}

Summary: In this paper, the author examines a work of one of the most significant Croatian literary writers, Ante Kovačić, whose novel $U$ registraturi (In the Registry Office) is considered by many literary critics and theoreticians to be the best writing of Croatian realism. It is an author who was not understood at the time when his work appeared, which is why the text was published in the form of a novel with a twenty-three year delay. Nonlinear composition of the text, elements of fantasy literature and innovative literary process in creating a fabula and sujet course of events confused literary critics as well as readership, which points to the fact that Ante Kovačić was treated for a long time as a peripheral author.

In this narrative text, the misery and helplessness of peasants and their revolt against their feudal lords in Croatia are described, therefore the object of our analysis will be the characterisation of figures from various layers of society, with a particular focus on the "peripheral characters" of Kovačić's prose. Using the term "peripheral characters" we will attempt to bring close those characters of subjugated peasants in relation to the feudal-capitalist social layer and thereby emphasise their role in the novel in relation to their fate.

Unlike the characters of the peasants - Ivica Kičmanović (whom the social order turns into a lackey and scoundrel); Jožica Zgubidan (the personification of a poor person from Zagorje), Anica (a patriarchal girl with an angelic face); Miha; Perica; the neighbouring Kanoniks; and the Medonjićes - Kovačić brings us harsh, drastic images of moral vacillations in the city in which figures, distorted into caricatures, dominate. By contrasting the rural environment with the city life, the author is writing an "epopee of the village and city" in which the "peripheral characters" become tragic ones. These characters are the carriers of elements of "fantastic realism," and their function is to show all the depravities of society and to announce the phenomenon of the innovative processes of narration familiar to authors of the modern literature.

Finally, we come to the conclusion that Ante Kovačić made a step forward in relation to the generation of realists, with the peripheral position of his creation disappearing with the emergence of modern literary achievements, which ultimately gives the author and his work a polished place in Croatian literature.

Keywords: Ante Kovačić, fantastic realism, innovative processes, demonic characters, social depravity 